\title{
Arachidonate 5-Lipoxygenase Establishes Adaptive Humoral Immunity by Controlling Primary B Cells and Their Cognate T-Cell Help
}

\author{
Tsutomu Nagashima, ${ }^{\star \dagger}$ Shingo Ichimiya, ${ }^{*}$ \\ Tomoki Kikuchi, ${ }^{*}$ Yoshiyuki Saito, ${ }^{*}$ \\ Hiroshi Matsumiya, ${ }^{* \dagger}$ Shihoko Ara, ${ }^{* \dagger}$ \\ Shigeru Koshiba, ${ }^{\dagger}$ Jun Zhang, ${ }^{*}$ Chizuru Hatate, ${ }^{*}$ \\ Akiko Tonooka, ${ }^{*}$ Terufumi Kubo, ${ }^{*}$ Rui Carrie Ye, ${ }^{*}$ \\ Bungo Hirose, ${ }^{*}$ Hideaki Shirasaki, ${ }^{\dagger}$ \\ Takashi Izumi, ${ }^{\ddagger}$ Tsuyoshi Takami, ${ }^{\S}$ Tetsuo Himi, ${ }^{\dagger}$ \\ and Noriyuki Sato*

\begin{abstract}
From the Departments of Pathology* and Otolaryngology, ${ }^{\dagger}$ Sapporo Medical University School of Medicine, Sapporo; the Department of

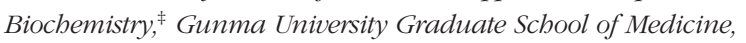
Maebashi; and the Department of Immunopatbology, ${ }^{\Im}$ Gifu University Graduate School of Medicine, Gifu, Japan
\end{abstract}

In this study, we report the unique role of arachidonate 5-lipoxygenase (Alox5) in the regulation of specific humoral immune responses. We previously reported an L22 monoclonal antibody with which human primary resting $B$ cells in the mantle zones of lymphoid follicles are well-defined. Proteomics analyses enabled identification of an L22 antigen as Alox5, which was highly expressed by naive and memory $B$ cells surrounding germinal centers. Cellular growth of mantle cell lymphoma cells also seemed to depend on Alox 5 . Alox $5^{-/-}$ mice exhibited weak antibody responses specific to foreign antigens at the initial and recall phases. This was probably attributable to the low number of follicular and memory $B$ cells and the functional loss of interleukin-21-mediated responses of follicular B cells. Moreover, Alox $5^{-/-}$mice could not fully foster the development of follicular B helper $T$ (Tfh) cells even after immunization with foreign antigens. Further experiments indicated that Alox5 affected mortality in experimentally induced enterocolitis in germ-prone circumstances, indicating that Alox 5 would endow immunologic milieu. Our results illustrate the novel role of Alox 5 in adaptive humoral immunity by managing primary B cells and Tfh cells in vivo. (Am J Pathol 2011, 178: 222-232; DOI: 10.1016/j.ajpath.2010.11.033)

Regulation of specific humoral responses directs a center of adaptive immunity to prevent infection, autoimmune disease, and cancer. ${ }^{1,2}$ Mechanisms underlying antibody production wholly depend on the cellular function of B cells. After the somatic mutation of genes encoding B-cell receptor (BCR) and its editing in the bone marrow, B cells are distributed to the peripheral lymphoid tissues, where they reside as primary resting $B$ cells. ${ }^{3,4}$ On stimulation of the surface $B C R$ s and with cognate help from $\mathrm{CD}^{+} \mathrm{T}$ cells, primary $\mathrm{B}$ cells differentiate into germinal center $\mathrm{B}$ cells, where somatic hypermutations and class switch recombination occur, resulting in further differentiation into plasma cells or memory B cells. It is considered that for the sake of efficient production of specific antibodies, primary resting B cells around germinal centers keep $\mathrm{BCR}$ repertories as a major anatomical source of lymphoid follicles. ${ }^{5}$ By the function of antiapoptotic factors, such as $\mathrm{Bcl}-2$, it is thought that primary B cells would survive and eventually maintain BCR repertoires in individuals. ${ }^{6}$ However, the mechanism underlying primary B-cell regulation has not yet been elucidated.

Previously, we created an L-series of monoclonal antibodies (mAbs) for use in the identification of immune cells by means of immunohistochemical analysis or flow cytometry. ${ }^{7-9}$ The L-series panel includes L26 mAbs, which specifically bind to the cytoplasmic domain of $\mathrm{CD} 20$. This $\mathrm{mAb}$ is widely used for immunopathologic examinations of lymphoid tissue to decipher B-cell-related disorders, including malignancies and immune-associated diseases. ${ }^{7,10}$ L22 mAbs have exhibited a unique distribution profile: L22 antigen (Ag) is specifically expressed in the cytoplasm of primary resting $B$ cells in the mantle zones of lymphoid follicles but not in activated $B$ cells of germinal centers and in T cells. ${ }^{8}$ Therefore, it is of great interest to investigate the nature of $L 22 \mathrm{Ag}$ because we consider that its functional features may provide new fundamental insights into the regulatory mechanism of adaptive humoral immune responses.

Supported by Grants-in-Aid for Scientific Research from the Japan Society of Promotion of Science (No. 20590347), the Japan Rheumatism Foundation, the Akiyama Foundation, and the Suhara Memorial Foundation (S.I.).

Accepted for publication September 23, 2010.

Supplemental material for this article is available at $h t t p: / / a j p . a m j p a t h o l$. org and at doi:10.1016/ajpath.2010.11.033.

Address reprint requests to Shingo Ichimiya, M.D., Ph.D., Assistant Professor, Department of Pathology, Sapporo Medical University School of Medicine, Sapporo, Hokkaido 060-8556, Japan. E-mail: ichimiya@sapmed.ac.jp. 
Herein, we first identified an L22 Ag as arachidonate 5-lipoxygenase (Alox5) and elucidated its unique role of coordinating specific antibody responses. Alox5 oxidizes arachidonic acid as a substrate initially to produce 5-hydroperoxy-6,8,11,14-eicosatetraenoic acid, which is an intermediate for various leukotrienes of lipid mediators. ${ }^{11}$ We observed that naive $\left(\mathrm{CD} 19^{+} \mathrm{CD} 23^{+} \mathrm{CD} 27^{-} \mathrm{CD} 38^{-}\right)$ and memory $\left(\mathrm{CD} 19^{+} \mathrm{CD} 23^{-} \mathrm{CD} 27^{+} \mathrm{CD} 38^{-}\right)$phenotypes of human primary $\mathrm{B}$ cells in the mantle zones preferentially expressed Alox5. ${ }^{12}$ Studies of Alox $5^{-1-}$ mice revealed that this enzyme was required for the humoral response against T-cell-dependent foreign antigens at the initial and recall phases. This was probably because of the loss of follicular B cells $\left(\mathrm{B} 22 \mathrm{O}^{+} \mathrm{CD} 21^{\mathrm{int}} \mathrm{CD} 23^{+}\right)$and memory $\mathrm{B}$ cells $\left(\mathrm{B} 22 \mathrm{O}^{+} \operatorname{lgG} 1^{+} \mathrm{NP}^{+}\right)$due to cell death in Alox $5^{-1-}$ mice. ${ }^{13}$ Furthermore, mantle cell lymphoma (MCL) would depend on the growth activities of Alox5, implying a growth regulatory role of Alox5 in normal primary B cells and their derived tumor cells. Moreover, note that $A / o \times 5^{-\prime-}$ mice showed fewer germinal center cells after immunization of the foreign antigens and developmental insufficiency of follicular B helper $\mathrm{T}$ (Tfh) cells $\left(\mathrm{CD}{ }^{+} \mathrm{CD} 4^{+} \mathrm{CD} 25^{-} \mathrm{CXCR}^{+}{ }^{+} \mathrm{ICOS}^{+}\right) \cdot{ }^{14,15}$ Experimental evidence has revealed that $A / 0 \times 5^{-/-}$and recombination activating gene $1^{-1-}\left(\operatorname{Rag}^{1^{-1-}}\right)$ chimera mice were fairly susceptible to the condition of enterocolitis, especially in conventional facilities; this reiterates the pivotal role of Alox5 in the regulation of specific antibody responses. In addition to the evidence indicating the possible role of Alox5 in MCL, these and further investigations may shed light on the association of lipid metabolism of arachidonic acid by Alox5 with the regulation of adaptive humoral immunity and the nature of MCLs. ${ }^{16-18}$

\section{Materials and Methods}

\section{Tissues and Cell Lines}

All tissues were obtained after receiving informed consent from the subjects and with the approval of the Institutional Review Board. Tonsillar tissues were obtained from patients undergoing tonsillectomy for the treatment of recurrent tonsillitis, and lymphoma tissues were obtained by means of biopsy. Portions of the tissues were stored at $-80^{\circ} \mathrm{C}$ as frozen tissue sections. Human embryonic kidney (HEK) 293 and P1.4 cells were maintained in Dulbecco's modified Eagle's medium supplemented with $10 \%$ fetal bovine serum, $50 \mu \mathrm{g} / \mathrm{ml}$ of streptomycin, and $100 \mathrm{U} / \mathrm{ml}$ of penicillin. Cell lines derived from MCL, including G519, HBL2, JEKO1, MINO, and REC1, as well as Jurkat, Molt4, and Daudi cells, were maintained in RPMI 1640 medium containing 10\% fetal bovine serum, 2 $\mathrm{mmol} / \mathrm{L}$ l-glutamine, $50 \mu \mathrm{g} / \mathrm{ml}$ of streptomycin, and 100 $\mathrm{U} / \mathrm{ml}$ of penicillin. All cells were cultured at $37^{\circ} \mathrm{C}$ in a humidified atmosphere with $5 \%$ carbon dioxide.

\section{Mice and Immunization}

All the experiments were performed in accordance with the institutional guidelines for the care and use of animals. Alox5 ${ }^{-/-}$mice ${ }^{19}$ and C57BL/6-SV129S F1 hybrid mice used as a control were purchased from The Jackson Laboratory (Bar Harbor, ME). All these mice were maintained in specific pathogen-free or conventional animal facilities of Sapporo Medical University School of Medicine. Age- (6 to 12 weeks) and sex-matched mice from each group, which were simultaneously raised in the same environment at the facilities, were used for the experiments. Lin ${ }^{-} \mathrm{Scal}^{+}$bone marrow stem cells of $A l o \times 5^{+/+}$or $A l o \times 5^{-1-}$ mice were transferred into recombination activating gene 1-deficient mice (C57BL/6 background; The Jackson Laboratory) to generate Rag ${ }^{-/-}$bone marrow chimera mice. Eight weeks after stem cell transplan-

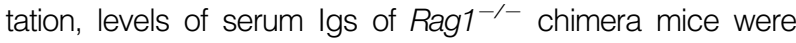
examined before being used for experiments. Mice were immunized by means of i.p. administration of $200 \mu \mathrm{L}$ of $5 \%$ sheep red blood cells (SRBCs) or $100 \mu \mathrm{g}$ of (4-hydroxy-3nitrophenylacetyl)36 coupled to chicken gamma globulin (NP36-CGG) (with alum at initial immunization).

\section{Reagents}

L22 (clone TB1-2C3) and TE4 mAbs were purified from mouse ascitic fluid and were used for immunoprecipitation and immunohistochemical analysis. The following antihuman mAbs were purchased from BD Biosciences (San Jose, CA): fluorescein isothiocyanate (FITC)-anti-CD3 (clone SK7), FITC-anti-CD4 (RPA-T4), FITC-anti-CD8 (clone RPA-T8), antigen-presenting cell (APC)-anti-CD19 (clone HIB19), phycoerythrin (PE) -Cy7-anti-CD25 (clone MA251), PE-anti-CD27 (clone MT271), FITC-anti-CD38 (clone HIT2), PE-anti-CD278 (ICOS; clone DX29), biotin-anti-CXCR5 (clone RF8B2), FITC-anti-IgD (clone IA6-2), FITC-anti-IgM (clone G20127), FITC-anti-IgG (clone G18-145), and Ig isotype control mAbs. Rabbit antihuman-CD23 mAbs (clone SP23), antihuman-Bcl-2 polyclonal antibodies (pAbs), and antihuman-Alox5 pAbs were obtained from Nichirei Bioscience Inc. (Tokyo, Japan), Neomarkers Inc. (Fremont, $\mathrm{CA}$ ), and Cayman Chemical Co (Ann Arbor, MI), respectively. The following antimouse mAbs were purchased from BD Biosciences, Affinity BioReagents Inc. (Golden, $\mathrm{CO}$ ), eBioscience Inc. (San Diego, CA), and Genetex Inc. (Irvine, CA): biotin-anti-CD1 days (clone 1B1), anti-CD3 (hamster clone 500A2), APC-anti-CD3 (clone 145-2C11), FITC-anti-CD4 (clone L3T4), PE-anti-CD8 (clone 53-6.7), anti-CD19 mAb (clone 1D3), FITC-anti-CD21 (clone 7G6), PE-anti-CD23 (clone B3B4), PE-Cy7-anti-CD25 (clone PC61), FITC- or APC-anti-CD45R/B220 (clone RA3-6B2), PE-anti-CD278 (ICOS; clone 7E17G9), biotin-anti-CXCR5 (clone 2G8), FITC-anti-lgG1 (clone LO-MG 1-2), biotin-anti-major histocompatibility complex class II (clone M5/114.15.2), and isotype control mAbs. Horseradish peroxidase-conjugated rabbit pAbs against isotypes were purchased from Southern Biotechnology (Birmingham, AL). Mouse anti-enhanced green fluorescent protein (EGFP) mAbs (clone JL-8) and biotin-conjugated peanut agglutinin were obtained from Vector Laboratories (Burlingame, CA) and Invitrogen (Carlsbad, CA), respectively. NP-CGG, 4-hydroxy-3nitrophenylacetyl coupled to bovine serum albumin (NP-BSA), and NP-BSA-biotin were purchased from Bioresearch Technologies Inc. (Novato, CA). 


\section{Immunohistochemical Analysis}

Procedures for tissue sections were conducted as described previously. ${ }^{20}$ In brief, tissue sections were stained with primary mAbs at $4^{\circ} \mathrm{C}$ overnight and then were reacted with secondary pAbs conjugated to Alexa Fluor (Molecular Probes Inc., Eugene, OR). Signals were detected using an immunofluorescence microscope (IX71; Olympus, Center Valley, PA) or a laser scanning confocal microscope (R2100AG2; Bio-Rad Laboratories, Hercules, CA).

\section{Immunoprecipitation and Immunoblotting}

Cells were treated in a lysis buffer solution consisting of $150 \mathrm{mmol} / \mathrm{L}$ sodium chloride, $50 \mathrm{mmol} / \mathrm{L}$ Tris-chloride $(\mathrm{pH}$ 7.5), $1 \mathrm{mmol} / \mathrm{L}$ EDTA, $0.3 \%$ Triton X-100 (Roche Diagnostics $\mathrm{GmbH}$, Mannheim, Germany), and protease inhibitors (Roche Diagnostics $\mathrm{GmbH}$ ) and then were subjected to immunoprecipitation or immunoblotting as described elsewhere. ${ }^{21}$ After washing the beads, the specimens were separated by $5 \%$ to $20 \%$ gradient SDS-polyacrylamide gel electrophoresis and were stained using a silver staining MS kit (Wako Chemicals USA Inc., Richmond, VA) or blotted onto an Immobilon-P membrane (Millipore, Billerica, MA) for immunoblotting. ${ }^{21}$

\section{Liquid Chromatography-Electrospray Ionization-Tandem Mass Spectrometry}

Trypsin was used for in-gel digestion of the specimens, after which they were analyzed using tandem mass spectrometry (Gene World, Tokyo, Japan). The obtained peptides were further investigated through a Mascot search to predict an original protein.

\section{Flow Cytometry and Cell Sorting}

Lymphocytes were purified by means of centrifugation with Lymphoprep (human; Axis-Shield, Oslo, Norway) or Lympholyte-M (mouse; Cedarlane Laboratories Ltd, Burlington, NC) and then were stained using standard flow cytometry. After preparation of cell specimens, cells were analyzed using a FACSCanto II flow cytometer with DiVA software (BD Biosciences). A FACSAria II cell sorter was used to select and analyze follicular B cells and Tfh cells. AutoMACS (Miltenyi Biotec Inc., Auburn, CA) was also used for magnetically purifying lymphocytes from human tonsils or primitive hematopoietic stem cells $\left(\mathrm{Lin}^{-} \mathrm{Scal}^{+}\right)$ from murine bone marrow. In each experiment, the purity of cells reached $95 \%$. Apoptotic cells were stained by annexin $\mathrm{V}$ and were detected using an APC dye according to the manufacturer's protocol (BD Biosciences).

\section{cDNA Transduction}

EGFP-tagged expression plasmids carrying human Alox5, sorting nexin 5 , sorting nexin 6 , or autoimmune regulator were used in this study. ${ }^{21,22}$ Plasmid DNAs were transfected into cells using LF2000 (Invitrogen).

\section{Enzyme-Linked Immunosorbent Assay}

A 96-well microtiter plate coated with SRBCs or NP-BSA was used to determine anti-SRBC and anti-NP Ig titers, as described previously. ${ }^{13,23} \mathrm{lg}$ isotypes of mice were determined using isotype-specific enzyme-linked immunosorbent assay (Southern Biotechnology).

\section{RT-PCR and Quantitative PCR}

Total RNA was extracted from cells using TRIzol (Invitrogen) and were reverse transcribed using oligo(dT) primers (Applied Biosystems, Foster City, CA). The RT-PCR primer pairs used in this study were designed as described previously and are summarized in Tables 1 and 2. ${ }^{20}$ Real-time PCR was performed using an ABI-PRISM 7900 according to the manufacturer's protocol (Applied Biosystems). Target gene expression was calculated using $\Delta \Delta \mathrm{CT}$ and comparative methods after normalization to 18S RNA or glyceraldehyde-3-phosphate dehydrogenase expression.

\section{Induction of Enterocolitis}

Experimental enterocolitis was induced in mice by supplementing drinking water with $1.5 \%$ dextran sodium sulfate (DSS; ICN Biomedicals, Irvine, CA), and the mice were monitored daily for survival as described previously. ${ }^{24}$ For evaluating histologic findings, the middle parts of the colon were removed and fixed with $10 \%$ formalin containing PBS. Then, paraffin-embedded tissue sections were stained with H\&E to examine histologic changes. The histologic score was examined as follows: epithelium (E), 0

Table 1. Mouse PCR Primer Pairs Used in This Study

\begin{tabular}{|c|c|c|c|c|c|}
\hline $\begin{array}{l}\text { Mouse } \\
\text { primers }\end{array}$ & Forward primer & $\begin{array}{c}\text { Genomic } \\
\text { region }\end{array}$ & Reverse primer & $\begin{array}{l}\text { Genomic } \\
\text { region }\end{array}$ & $\begin{array}{c}\text { Expected } \\
\text { length (bp) }\end{array}$ \\
\hline IL-6 & 5'-AGTTGCCTTCTTGGGACTGA-3' & Exon 2 & 5'-CAGAATTGCCATTGCACAA-3' & Exon 3 & 191 \\
\hline IFN- $\gamma$ & $5^{\prime}-$ ACTGGCAAAAGGATGGTGAC-3' & Exon 2-3 & 5'-TGAGCTCATTGAATGCTTGG-3' & Exon 4 & 237 \\
\hline IL-4R $\alpha$ & $5^{\prime}-\mathrm{CCTCACACTCCACACCAATG-3'}$ & Exon 6 & 5'-AGCCTGGGTTCCTTGTAGGT-3' & Exon 7 & 168 \\
\hline IL-21R & $5^{\prime}-$ TGTCAATGTGACGGACCAGT-3' & Exon 4 & $5^{\prime}$-CACGTAGTTGGAGGGTTCGT-3' & Exon 5 & 163 \\
\hline IFN- $\gamma \mathrm{R} 1$ & $5^{\prime}-\mathrm{TCCTGCACCAACATTTCTGA-3'}$ & Exon 3 & $5^{\prime}$-TACGAGGACGGAGAGCTGTT-3' & Exon 4 & 213 \\
\hline IFN- $\gamma R 2$ & $5^{\prime}$-GCTTCACCCTGTTCCTCAAA-3' & Exon 6 & $5^{\prime}$-AGCACATCATCTCGCTCCTT-3' & Exon 7 & 205 \\
\hline TLR4 & $5^{\prime}$-GCTTTCACCTCTGCCTTCAC-3' & Exon 3 & $5^{\prime}$-GAAACTGCCATGTTTGAGCA-3' & Exon 3 & 174 \\
\hline TLR7 & 5'-CCTGTTCTACTGGGGTCCAA-3' & Exon 3 & $5^{\prime}$-GCCTCAAGGCTCAGAAGATG-3' & Exon 3 & 167 \\
\hline TLR9 & 5'-GCTTTGGCCTTTCACTCTTG-3' & Exon 2 & 5'-AACTGCGCTCTGTGCCTTAT-3' & Exon 2 & 194 \\
\hline Alox5 & 5'-CTACGATGTCACCGTGGATG-3' & Exon 2 & $5^{\prime}$-GTGCTGCTTGAGGATGTGAA-3' & Exon 3 & 235 \\
\hline
\end{tabular}


Table 2. Human PCR Primer Pairs Used in This Study

\begin{tabular}{|c|c|c|c|c|c|}
\hline $\begin{array}{l}\text { Human } \\
\text { primers }\end{array}$ & Forward primer & $\begin{array}{c}\text { Genomic } \\
\text { region }\end{array}$ & Reverse primer & $\begin{array}{c}\text { Genomic } \\
\text { region }\end{array}$ & $\begin{array}{l}\text { Expected } \\
\text { length (bp) }\end{array}$ \\
\hline BLT1 & 5'-TTGCTCACTGCTCССТTTTT-3' & Exon 2 & 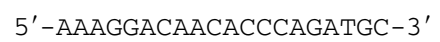 & Exon 2 & 237 \\
\hline BLT2 & 5'-GAGACTCTGACCGCTTTCGT-3' & Exon 1 & 5'-AAGGTTGACTGCGTGGTAGG-3' & Exon 1 & 183 \\
\hline CysLTR1 & $5^{\prime}-$ TGATGACTTCCGCAATCAAG-3' & Exon 3 & $5^{\prime}$-AGCCAAATGCCTTTGTGAAC-3' & Exon 3 & 216 \\
\hline CysLTR2 & 5'-TCCACTTGACGACATGGAAA-3' & Exon 1 & 5'-GGCCTTTTCTGAGTGCAGAC-3' & Exon 1 & 165 \\
\hline MAF & $5^{\prime}-$ TGGAGTCGGAGAAGAACCAG-3' & Exon 1 & $5^{\prime}$-GCTTCCAAAATGTGGCGTAT-3' & Exon 2 & 228 \\
\hline BCL-6 & $5^{\prime}-\mathrm{AACCTGAAAACCCACACTCG-3^{ \prime }}$ & Exon 8 & $5^{\prime}$-TGACGGAAATGCAGGTTACA - $3^{\prime}$ & Exon 9 & 245 \\
\hline CXCR5 & $5^{\prime}-$ CTCCCAAGAGAACCAAGCAG- $3^{\prime}$ & Exon 2 & $5^{\prime}-$ CCAGCAGAGGAAGAAGATGC- $3^{\prime}$ & Exon 2 & 205 \\
\hline IL-21 & $5^{\prime}-$ TTCTGCCAGCTCCAGAAGAT-3' & Exon 2 & 5'-TTGTGGAAGGTGGTTTCCTC-3' & Exon 3 & 153 \\
\hline
\end{tabular}

$=$ normal morphologic features; $1=$ loss of goblet cells; $2=$ loss of goblet cells in large areas; $3=$ loss of crypts; and 4 $=$ in large areas; infiltration (I), $0=$ no infiltrate; $1=$ infiltrate around the crypt basis; 2 = infiltrate reaching the lamina muscularis mucosae; $3=$ extensive infiltration reaching the lamina muscularis mucosae and thickening of the mucosa with abundant edema; and $4=$ infiltration of the lamina submucosa. The total histologic score was obtained by $\mathrm{E}+\mathrm{I}$.

\section{Cell Growth Assay}

Growth activities of cultured cells were investigated using a premix WST-1 cell proliferation assay system as per the manufacturer's instructions (Takara Bio Inc., Shiga, Japan).

\section{Statistical Analysis}

Results are expressed as mean and SE; the unpaired $t$-test was used to compare experimental groups unless otherwise stated, with $P<0.05$ considered significant.

\section{Results}

\section{L22 Ags in Primary B Cells Are Identical to Alox5}

Mouse L22 mAbs were originally established by immunizing mice with human tonsillar lymphocytes per standard procedures. ${ }^{8}$ Immunohistochemical analysis of tonsillar tissues demonstrated preferential distribution of L22 Ags in the cytoplasm of primary resting $B$ cells in the mantle zones of germinal centers in lymphoid tissues (Figure 1, A and B). ${ }^{25}$ We further examined the colocalization of L22 Ags with $\mathrm{CD} 23$, which was restricted to the $\operatorname{lgM}^{+}$or $\operatorname{lgD}^{+}$naive B-cell phenotype and were subsequently lost in germinal center and memory B cells. ${ }^{5,26,27}$ Primary B cells of the mantle zones were found to contain a mixed population of $\mathrm{L} 22^{+} \mathrm{CD} 23^{+}$and $\mathrm{L}_{22}{ }^{+} \mathrm{CD} 23^{-}$cells, indicating that primary $B$ cells around germinal centers consisted of $\mathrm{CD} 23^{+}$naive $B$ cells and $\mathrm{CD}_{23^{-}}$memory $\mathrm{B}$ cells, both of which presented L22 Ags (Figure 1C). Follicular dendritic cells of germinal centers also present CD23; however, L22 Ags were not expressed in $\mathrm{CD}_{23}{ }^{+}$follicular dendritic cells within germinal centers. ${ }^{28}$ Collectively, L22 Ags were expressed by primary $\mathrm{B}$ cells with naive and memory phenotypes but not in follicular dendritic cells.

To identify the molecular nature of L22 Ags, we initially used L22 mAbs to perform immunoprecipitation on tonsillar lymphocytes and cell lines. After trials with lysis buffers containing different types of detergents and under different experimental conditions, a clear band was detected at approximately $78 \mathrm{kDa}$ (Figure 1D). Such a band was also detected in Daudi B cells but not in Jurkat T cells and P1.4 thymic epithelial cells; these results concur with the tissue distribution of L22 Ags in human lymphoid tissues of the tonsils and thymus. Proteomics analysis of the protein band derived from tonsillar lymphocytes revealed the presence of at least four different peptides, all of which were completely matched to a core protein sequence of Alox5 (Figure 1E). Further immunoprecipitation and immunostaining experiments in which a plasmid DNA encoding EGFP-tagged Alox 5 was introduced into HEK 293 cells indicated the binding specificity of L22 mAbs to Alox5 (Figure 1, F and G).

\section{Primary B Cells Are Susceptible to Functional Loss of Alox5}

To investigate the tissue distribution of L22 Ags, primary resting naive $\left(\mathrm{CD} 19^{+} \mathrm{CD} 27^{-} \mathrm{CD} 38^{-}\right)$and memory $\left(\mathrm{CD} 19^{+} \mathrm{CD} 27^{+} \mathrm{CD} 38^{-}\right) \mathrm{B}$ cells were sorted and analyzed (see Supplemental Figure S1 at http://ajp.amjpathol. org). ${ }^{27,29}$ Quantitative PCR and immunoblot analyses demonstrated high Alox5 expression in naive and memory $B$ cells, which were also noted to be with or without CD23, respectively (Figure 2, A and B). Meanwhile, germinal center $B$ cells $\left(C D 19^{+} \mathrm{CD}_{2} 7^{-} \mathrm{IgD}{ }^{+}\right)$expressed very low levels of Alox5; these results are in accordance with those shown in Figure 1, A-C. However, Alox5 was not detected in $\mathrm{CD}^{+}$and $\mathrm{CD} 8^{+} \mathrm{T}$ cells.

To further address the functional role of Alox 5 in $\mathrm{B}$ cells, we cultured tonsillar B cells $\left(\mathrm{CD} 19^{+}\right)$with or without Alox5 inhibitors of MK886 or AA861 and studied the Bcell population therein. We observed that primary $B$ cells easily perished in the presence of MK886 or AA861 (Figure 2 C). Taking this result into account, we considered Alox5 to be a potential regulator of the maintenance of human naive and memory $B$ cells.

By means of two different types of receptors, namely, BCRs and Toll-like receptors (TLRs), B cells sense various antigens. ${ }^{2-6,30}$ When BCRs of tonsilderived B cells were stimulated, the cells could secrete leukotrienes (data not shown). ${ }^{11,31}$ This indicates that leukotrienes derived from naive and memory B cells, by affecting $B$ cells themselves or surrounding immune cells in lymphoid tissues, might act as a prompt dispatch mode to the subsequent antibody response. 
A

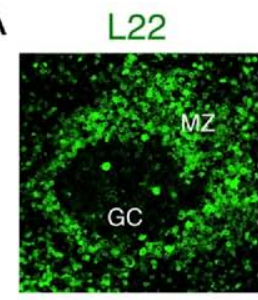

B

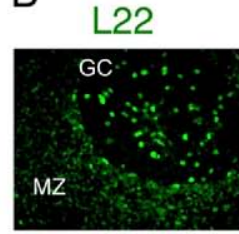

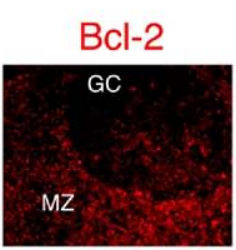

$E$
D Tonsillar

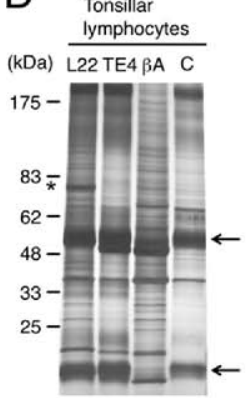

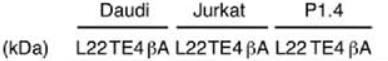

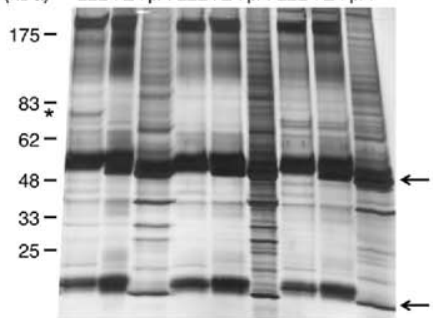

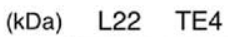

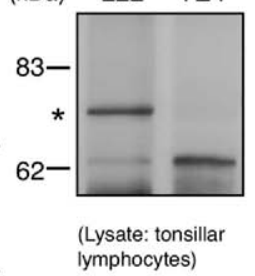

C

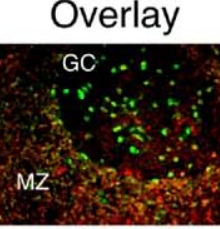

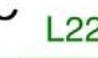
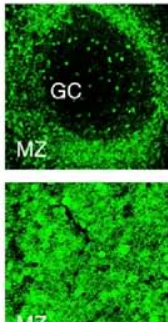
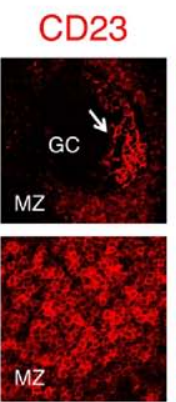

Overlay

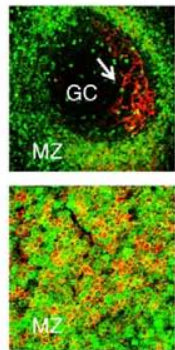

Human arachidonate 5-lipoxygenase (674 aa, pl: 5.51, MW: $78 \mathrm{kDa}$ )

1 MPSYTVTVATGSQWFAGTDDYIYLSLVGSAGCSEKHLLDKPFYNDFERGAVDSYDVTVDE 61 ELGEIQLVRIEKRKYWLNDDWYLKYITLKTPHGDYIEFPCYRWITGDVEVVLRDGRAKLA 121 RDDQIHILKQHRRKELETRQKQYRWMEWNPGFPLSIDAKCHKDLPRDIQFDSEKGVDFVI 181 NYSKAMENLFINRFMHMFQSSWNDFADFEKIFVKISNTISERVMNHWQEDLMFGYQELNG 241 CNPVLIRRCTELPEKLPVTTEMVECSLEROLSLEOEVQOGNIFIVDFELLDGIDANKTDP 241 CNPVLIRRCTELPEKLPVTTEMVECSLERQLSLEQEVQQGNIFIVDFELLDGIDANKTDP
301 CTLQFLAAPICLLYKNLANKIVPIAIQLNQI PGDENPIFLPSDAKYDWLLAKIWVRSSDF 361 HVHQTITHLLRTHLVSEVFGIAMYRQLPAVHPIFKLLVAHVRFTIAINTKAREQLICECC 421 LFDKANATGGGGHVQMVQRAMKDLTYASLCFPEAIKARGMESKEDIPYYFYRDDGLLVW: 481 AIRTFTAEVVDTYYEGDQVVEEDPELQDFVNDVYVYGMRGRKSSGFPKSVKSREQLSEYL 541 TVVIFTASAQHAAVNFGQYDWCSWIPNAPPTMRAPPPTAKGVVTIEQIVDTLPDRGRSCW 601 HLGAVWALSQFQENELFLGMYPEEHFIEKPVKEAMARFRKNLEAIVSVIAERNKKKQLPY 661 YYLSPDRIPNSVAI

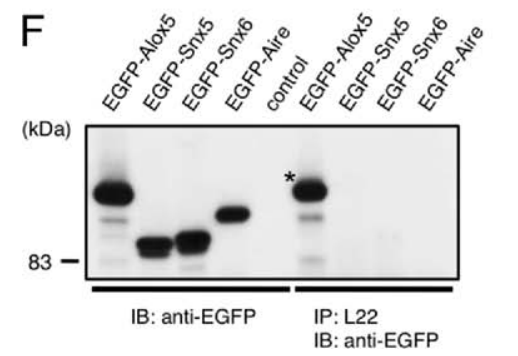

G
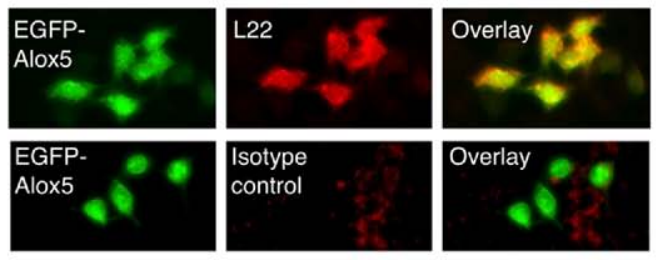

Figure 1. Mantle zone B cells of lymphoid tissues highly express Alox5. A-C: Immunohistochemical analysis of lymphoid follicles of tonsils with L22 mAbs. A: Mantle zone B cells around germinal centers express L22 Ag (green). Original magnification, X200. B: Mantle zone B cells with L22 Ag (green) simultaneously express Bcl-2 (red). Original magnification, $\times 200$. C: The mantle zone exhibits a mixed population of L22 $2^{+} \mathrm{CD} 23^{+}$and L22 $2^{+} \mathrm{CD} 23^{-} \mathrm{B}$ cells. Upper panel shows the lymphoid follicle containing follicular dendritic cells (arrows). Lower panel focuses on the mantle zone. Original magnification: $\times 200$ (upper panel); $\times 400$ (lower panel). In $\mathbf{A}, \mathbf{B}$, and $\mathbf{C}$, the mantle zone and germinal center are represented as MZ and GC, respectively. The large L22-expressing cells within the GC are macrophages. D: Immunoprecipitation analysis of tonsillar lymphocytes and cell lines with L22 mAbs. After separation of immunoprecipitates, the proteins were visualized by silver staining. The left and right panels demonstrate bands that resulted from the lymphocytes of tonsils and cell lines, including Daudi B cells, Jurkat T cells, and P1.4 thymic epithelial cells. The band that specifically reacts to L22 mAbs is indicated by asterisks in each panel. L22, L22 mAbs; TE4, antithymic medullary epithelium mAbs; $\beta \mathrm{A}$, anti- $\beta$-actin mAbs; C, isotype control. Arrows indicate light or heavy Ig chains bound to beads. E: Proteomics analysis of L22 Ags for identifying Alox5. Mass spectrometry of the band is indicated by an asterisk [left panel; same as (D)] revealed four different peptide sequences, including GVDFVLNYSK, AMENLFINR, YDWLLAK, and FTIAINTK. The protein sequence of Alox 5 is shown in the right panel, where the four peptides are depicted in red, as directed by a Mascot search. F: Immunoprecipitation analysis of EGFP-tagged Alox 5 and other human proteins with L22 mAb. HEK 293 cells were transiently transfected with a plasmid expressing EGFP-Alox5, EGFP-sorting nexin 5 (Snx5), EGFP-sorting nexin 6 (Snx6), or EGFP-autoimmune regulator (Aire), with expected molecular weights of 118, 86, 88, and $98 \mathrm{kDa}$, respectively. L22 mAbs bind to EGFP-Alox 5 (asterisk) but not to other EGFP-tagged proteins. G: Immunohistochemical analysis of HEK 293 cells expressing EGFP-Alox 5 with L22 mAb. L22 mAb (red) reacts to cells transiently expressing EGFP-Alox 5 (green). Original magnification, $\times 400$.

\section{Alox5 Is Required for Specific Humoral Immune Responses}

Next, we immunized Alox $5^{-1-}$ mice with various antigens and investigated their sera and immune cells. When SRBCs were administered as T-cell-dependent foreign antigens, these mice showed impaired production of SRBC-specific antibodies at the initial and recall phases (Figure 3, A and B). To further examine the role of Alox5 in B cells, we established bone marrow chimeras of Rag $^{-1-}$ mice lacking $B$ and $T$ cells. $\mathrm{Lin}^{-} \mathrm{Scal}^{+}$cells from the bone marrow of $\mathrm{AlO} \times 5^{+/+}$or Alox $5^{-1-}$ mice were transplanted into Rag $1^{-1-}$ mice (termed Rag $1^{W T}$ or Rag $1^{A l o x 5}$ mice, respectively). When immunized with SRBC, Rag1 $1^{\text {Alox5 }}$ could not fully produce SRBC-specific antibodies, whereas Rag $1^{W T}$ mice could (Figure 3D). These results strongly suggested the requirement of Alox5 to produce specific antibodies from B cells.

Most Ig subclasses examined were at normal serum levels in unimmunized $A / 0 \times 5^{-1-}$ mice, suggesting that Alox5 was not necessary to produce naturally occurring lgs (Figure 3C). To our surprise, however, IgG2a levels dependent on type 1 helper $T$ cells were significantly reduced in Alox $5^{-1-}$ mice even after SRBC immunization (Figure 3, A and C). Similarly, Rag $1^{\text {Alox } 5}$ mice demonstrated low levels of IgG2a compared with Rag ${ }^{W T}$ mice (data not shown). The inability of IgG2a production by $A / 0 \times 5^{-1-}$ and Rag $1^{\text {Alox } 5}$ mice suggests the possible involvement of Alox5 in an unknown mechanism of class switching of the IgG2a heavy chain within B cells or of insufficient effects from neighboring cells such as helper T cells. ${ }^{32,33}$ 
A

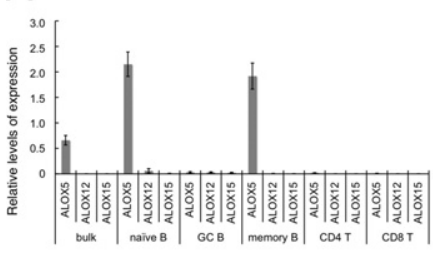

C

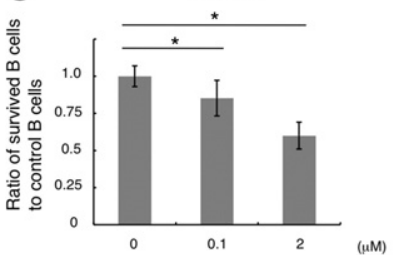

B
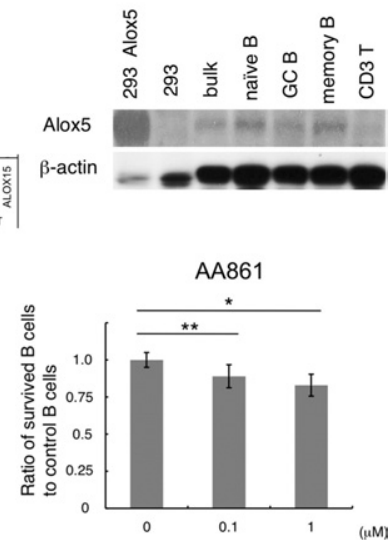

Figure 2. Expression and function of Alox 5 in primary resting B cells. A: Quantitative PCR analysis of Alox 5 in tonsillar lymphocytes. On the basis of the oxidation site of arachidonic acid, lipid oxidation enzymes are categorized into three types: Alox5, Alox12, and Alox15. Naive and memory B cells preferentially express transcripts of Alox 5 but not Alox 12 and Alox15. B: Immunoblotting analysis of Alox 5 in tonsillar lymphocytes. Alox 5 is abundantly expressed in naive and memory B cells. HEK 293 cells and their transient transformants expressing Alox 5 were used as controls C: B cells require Alox 5 for their survival. $2 \times 10^{6} \mathrm{CD} 19^{+}$B cells from tonsils were cultured in serum-free AIM V medium (Invitrogen) in each well of a 24-well plate with or without MK886 or AA861 for 96 hours, and then flow cytometric analysis of $\mathrm{B}$ cells was performed. The data are demonstrated as the ratios of the $\mathrm{CD} 19^{+}$population in the control media to these cells in the inhibitor-containing media, where the cells were counted as $\mathrm{CD} 19^{+}$cells. Results are representative of three to four independent experiments. ${ }^{*} P<0.1,{ }^{* *} P<0.05$.

Furthermore, we investigated the role of Alox5 in the regulation of memory-specific humoral responses. When the mice were administered NP36-CGG, although memory $\mathrm{B}$ cells with the $\mathrm{B} 22 \mathrm{O}^{+} \operatorname{lgG} 1^{+} \mathrm{NP}^{+}$phenotype were indeed

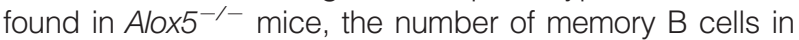
Alox $5^{-1-}$ mice was almost half the number in $\mathrm{Alo} \times 5^{+/+}$mice (Figure 3E). The serum titer of NP25-BSA or NP3-BSA specific IgG1 increased in Alox $5^{+/+}$mice in response to the second challenge of NP36-CGG; however, this titer did not

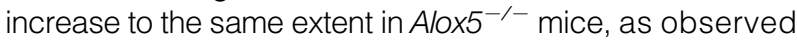
in the SRBC immunization experiment (Figure 3F). Meanwhile, there were no significant differences in a ratio of the titer of NP25-BSA to that of NP3-BSA in Alox $5^{+/+}$and Alox $5^{-/-}$mice at each date of investigation (Figure $3 \mathrm{G}$ ). Therefore, Alox5 might regulate the number of memory B cells, whereas Alox 5 would not be required for the processes of affinity maturation. ${ }^{23}$

\section{Alox5 Regulates Survival and Function of Follicular B Cells}

As previously reported, the spleen is relatively smaller in Alox $5^{-1-}$ mice than in wild-type mice (Figure 4A). ${ }^{19}$ When immunized with SRBCs, the spleen of $\mathrm{Alox5^{+/+ }}$ mice gradually increased in weight up to approximately double the original weight. Immunization also increased the spleen weight in $\mathrm{AlO} \times 5^{+/-}$and Alox $5^{-1-}$ mice; however, the spleens were smaller and their weights did not reach the weight attained by Alox $5^{+/+}$mice. Inverted microscopy revealed that lymphoid nodules of the spleen did not develop well in Alox $5^{+/-}$and $A l o x 5^{-1-}$ mice even after administration of SRBCs (Figure 4B). Indeed, immunohistochemical studies revealed fewer mature germinal centers in the lymphoid follicles in the spleen of SRBCimmunized Alox5 $5^{-1-}$ mice (Figure $4 \mathrm{C}$ ). Furthermore, flow cytometry analysis indicated reduced numbers of germinal center cells $\left(B 220^{+} \mathrm{PNA}^{+} \mathrm{IgD}^{-}\right)$in SRBC-immunized Alox $5^{-1-}$ mice (Figure 4D). These results suggest that the weak humoral responses to foreign antigens in Alox $5^{-1-}$ mice may be caused by inability to generate sufficient germinal centers.

Freshly isolated spleens of $A l o x 5^{-1-}$ mice had slightly

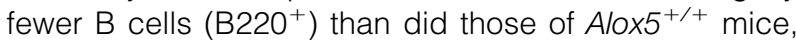
even after SRBC immunization. Primary resting $B$ cells are generally classified into 2 major subpopulationsfollicular B cells $\left(\mathrm{B} 220^{+} \mathrm{CD} 21^{\text {int }} \mathrm{CD} 23^{+}\right)$and marginal zone $\mathrm{B}$ cells $\left(\mathrm{B} 22 \mathrm{O}^{+} \mathrm{CD} 21^{\mathrm{hi}} \mathrm{CD} 23^{-}\right)$, each of which plays a unique role in the humoral immune response. ${ }^{34,35}$ Follicular B cells play an important role in antibody production in a T-cell-dependent manner, and marginal zone B cells are considered to be innate-like cells. Interestingly, Alox $5^{-1-}$ mice demonstrated a significantly decreased number of follicular B cells, ie, approximately $60 \%$ of the number of cells in Alox $5^{+/+}$mice (Figure 4E). We also observed the same tendency of follicular B cells in the spleen of Rag $1^{\text {Alox5 }}$ mice compared with those of Rag ${ }^{W T}$ mice (Figure 4F). Note that Alox5 deficiency could lead to apoptosis of follicular B cells, as assessed by the cell surface expression of annexin $V$ (Figure 4G). ${ }^{36}$ These evidences imply that follicular B cells depend on Alox5 for maintaining the B-cell population; ie, the B-cell repertoires might be preserved by Alox5 to effectively produce specific antibodies.

We further investigated the features of follicular B cells of Alox $5^{-1-}$ mice. After examination of various molecules related to antibody production, the expression levels of the interleukin-21 (IL-21) receptor were profoundly reduced in follicular B cells of Alox $5^{-1-}$ mice (Figure $\left.4 \mathrm{H}\right) .{ }^{37,38}$ However, levels of $\mathrm{IL}-6$, interferon $\gamma$ receptors, and TLRs were not significantly altered in these cells. Similarly, there were no differences in the major histocompatibility complex class II expression of follicular B cells in Alox $5^{+/+}$and Alox $5^{-/-}$ mice, suggesting that Alox5 of follicular B cells might not affect the cellular presentation of foreign antigens to helper T cells (Figure 4I). Because Alox5 regulates the cell fate and IL-21-mediated responses of follicular B cells, Alox5-deficient mice might become incapable of producing antibodies specific to foreign antigens.

\section{Alox5 Is Involved in the Generation of Tfh Cells}

As noted, IgG2a is preferentially regulated by type 1 helper $\mathrm{T}$ cells; therefore, we considered the possible functional effect of Alox5 in the development of effector helper $\mathrm{T}$ cells. This might also be suggested by evidence that professional APCs other than primary B cells, such as macrophages or dendritic cells, possess Alox5. ${ }^{11,39}$ Before this investigation, we analyzed the status of thymic

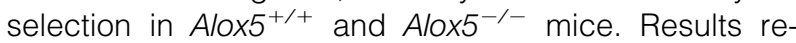
vealed no significant differences between the populations of developing thymocytes in $\mathrm{AlO}^{+/ /+}$and $\mathrm{Alox5^{-/- }}$ 
A

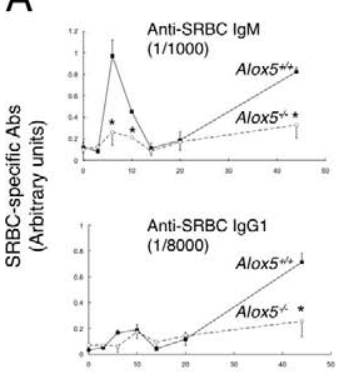

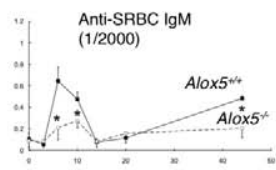

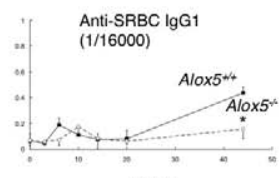

Days

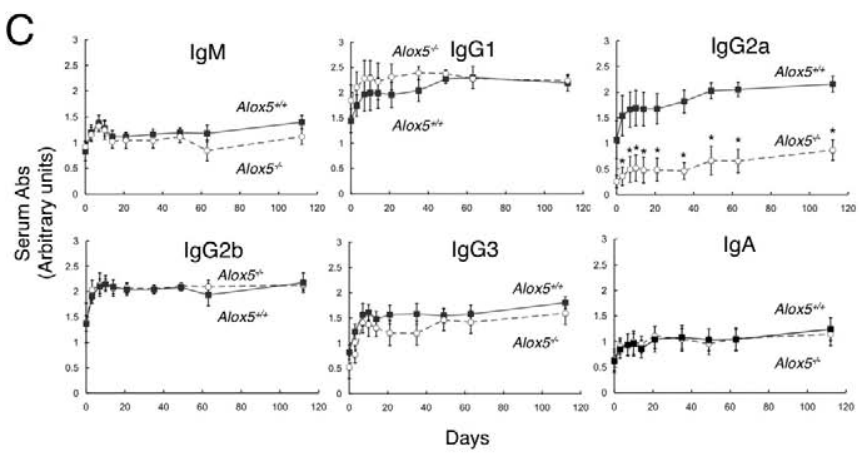

F

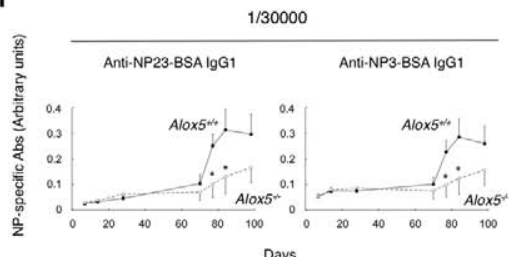

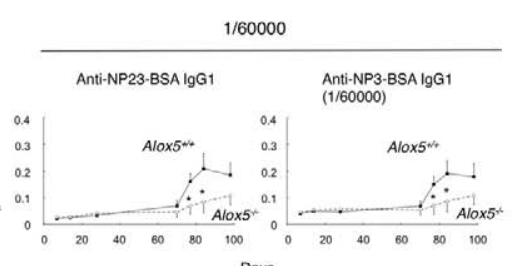

B
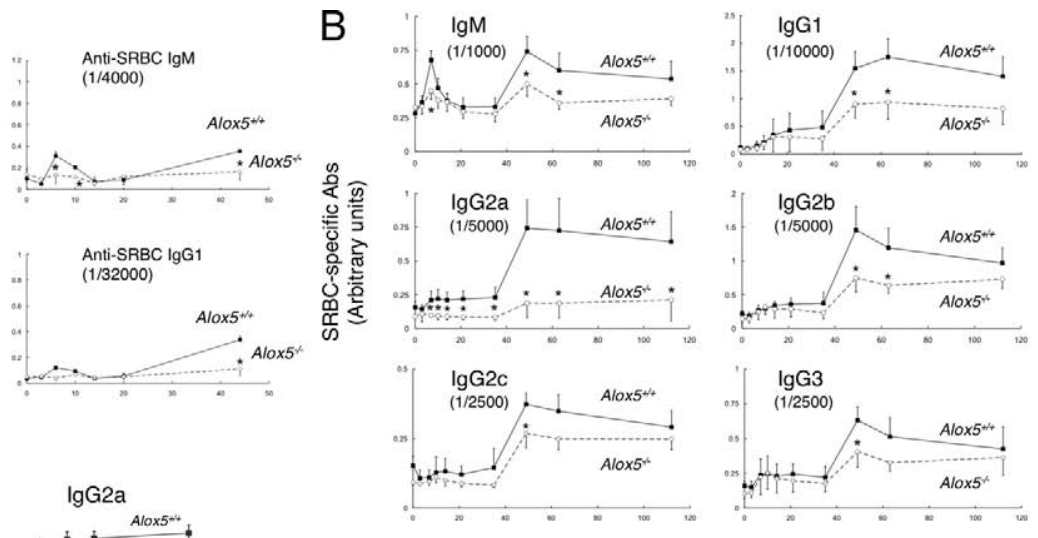

$\operatorname{lgG3}$

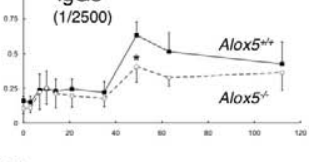

Days

D

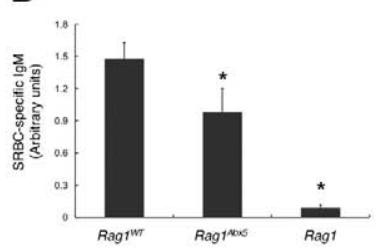

E

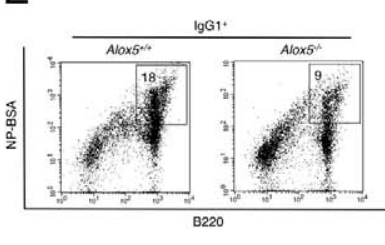

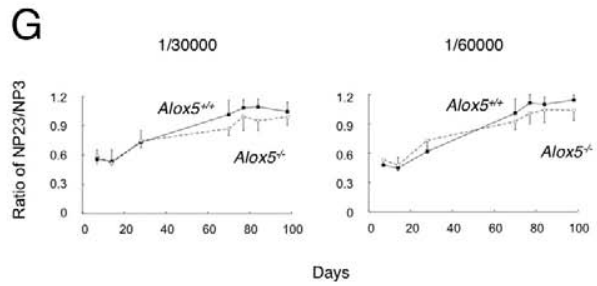

Figure 3. Functional defects of antibody responses specific to foreign antigens of Alox 5 -deficient mice. A: SRBC-specific serum titers of IgM and IgG1 of $A$ lox $5^{+/}$ and Alox $5^{-1}$ mice. Mice were immunized with SRBCs on days 0 and 28. SRBC specific IgM and IgG1 titers on consecutive days are shown in different dilutions. $n=6$ to 8 mice per group. B: SRBC specific serum Ig titers of Alox $5^{+/+}$and Alox $5^{-1}$ mice. The mice were immunized with SRBCs on days 0 and 42 . Titers of SRBC specific IgM, IgG1, IgG2a, IgG2b, IgG2c, and IgG3 on consecutive days are shown in different dilutions. $n=7$ to 10 mice per group. C: Impairment of IgG2a production in Alox $5^{-1}$ mice. Serum levels of IgM, IgG1, IgG2a, IgG2b, IgG3, and IgA of the specimens studied in B are demonstrated. D: SRBC specific serum titers of IgM of $\operatorname{Rag} 1^{W T}$ and $\operatorname{Rag} 1^{\text {Alox }}$ mice. Before immunization, Rag 1 chimera mice were examined for whether they produced Igs. Then mice were immunized with SRBCs on day 0, and the titers of SRBC specific IgM on day 7 are presented. Results from Rag 1 are also shown as a control. $n=5$ to 6 mice per group. E: Low numbers of memory B cells (B220 ${ }^{+} \mathrm{IgG}^{+} \mathrm{NP}^{+}$) in Alox $5^{-1}$ mice. Mice were immunized with NP36-CGG on days 0 and 56 . FACS analysis was used to assess $\mathrm{B}$ cells in the spleen on day 64 . After gating $\mathrm{IgG}^{+}$cells, B220 ${ }^{+} \mathrm{NP}^{+}$cells were found to compose $18 \%$ and $9 \%$ of $\mathrm{IgG} 1^{+}$cells in $\mathrm{Alo} \times 5^{+/+}$and Alox $5^{-1-}$ mice, respectively. $n=4$ to 6 mice in each group. F: Recall antibody responses of Alox $5^{+/+}$and Alox $5 /-$ mice. The mice were immunized with NP36-CGG on days 0 and 63. Titers of NP23-BSA or NP3-BSA specific IgG1 at consecutive days are shown at different dilutions. $n=6$ mice per group. G: Ratio of the titer of NP23 specific IgG1 to NP3 specific IgG1 obtained in $\mathbf{F}$. No significant differences were observed between the ratios in $A$ lox $5^{+/+}$and Alox $5^{-1}$ mice. Results of Alox $5^{+/+}$and Alox $5^{-1-}$ mice are depicted as solid and dashed lines, respectively. $n=6$ to 10 mice per group. ${ }^{*} P<.05$ compared with the wild-type control.

mice (Figure 5A). Previous studies have indicated the diversification of peripheral naive helper $T$ cells into different types of helper T cells, among which Tfh cells $\left(\mathrm{CD}^{+}{ }^{+} \mathrm{CD} 4^{+} \mathrm{CD}_{25}{ }^{-} \mathrm{CXCR}^{+}{ }^{+} \mathrm{COS}^{+}\right)$have the distinguished property of driving specific antibody responses. ${ }^{14,15}$ When a population of Tfh cells was studied, Alo $\times 5^{-/-}$mice unexpectedly lost their capacity to develop Tfh cells after SRBC immunization (Figure 5B). We next investigated the expression of receptors for Alox5related lipid mediators in Tfh cells derived from human tonsils in two cases (Figure 5C). In these cases, Tfh cells rather than control helper $\mathrm{T}$ cells $\left(\mathrm{CD}^{+}{ }^{+} \mathrm{CD} 4^{+}\right)$up-regulated the expression of $\mathrm{v}$-maf musculoaponeurotic fibrosarcoma oncogene (MAF), Bcl-6, and IL-21, as reported in previous studies. ${ }^{40-42}$ The control helper $\mathrm{T}$ cells expressed leukotriene receptors of BLT1 and BLT2 for leukotriene B4 and CysLTR1 or CysLTR2 for cysteinyl leu- kotrienes. In contrast, the levels of these receptors in Tfh cells seemed to be down-regulated or similar to those in control helper T cells. In fact, when human tonsillar T cells were examined by means of flow cytometry, $\mathrm{CD} 4^{+} \mathrm{T}$ cells frequently presented BLT1 on the cell surface, but BLT1 was lost in Tfh cells (data not shown). These results imply that the signaling of Alox5-related lipid mediators would be required during the initiation of differentiation of naive helper T cells to Tfh cells, probably while in contact with professional APCs.

\section{Alox5 Ensures Survival of Mice from Chronic Enterocolitis under Conventional Conditions}

Our observations suggest the novel role of Alox5 in the regulation of adaptive humoral responses. To investigate 
A

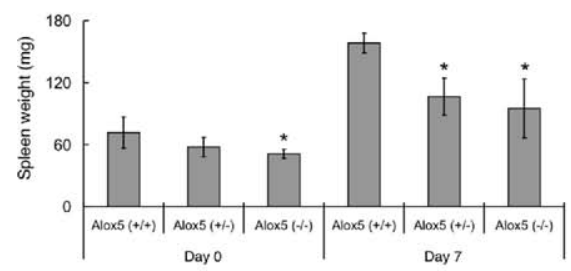

Day 0

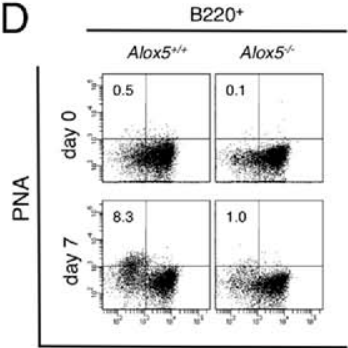

$\lg D$

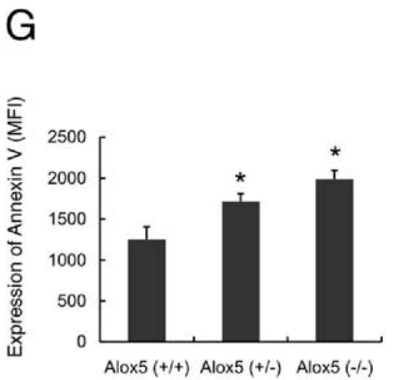

B

Day 0

Day 7

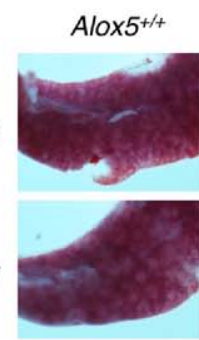

E

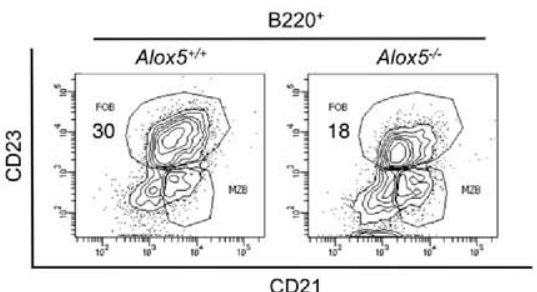

$\mathrm{H}$

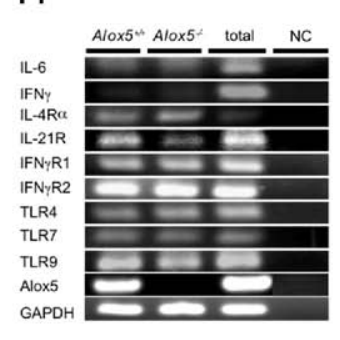

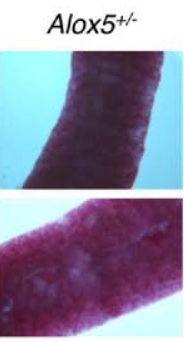

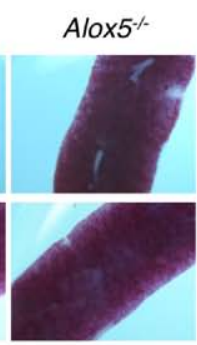

$\mathrm{F}$

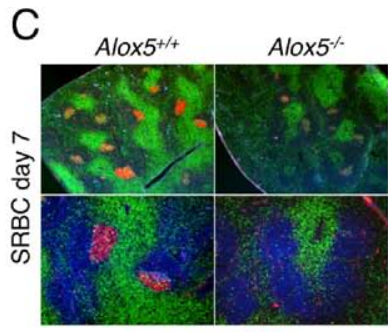

CD3 CD19 PNA

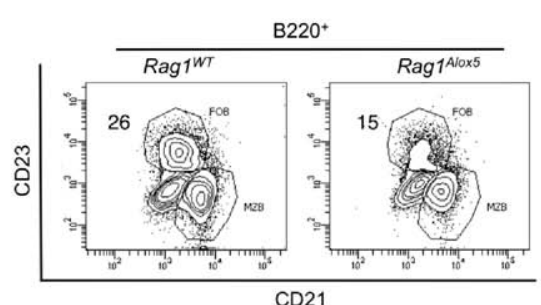

CD21

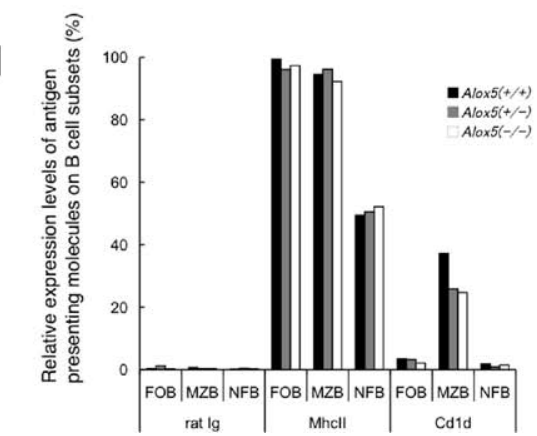

Figure 4. Analysis of antibody-producing cells in Alox5-deficient mice. A: Spleen weights of Alox $5^{+/+}$, Alox $5^{+/-}$, and Alox $5^{/-}$mice before (day 0 ) and after immunization with SRBCs (day 7). B: Features of the spleens of Alox $5^{+/+}$, Alox $5^{+/-}$, and Alox $5^{--}$mice before (day 0) and after (day 7) immunization with SRBCs as examined using a stereomicroscope (SZX7, Olympus). Original magnification, $\times 15$. C: Immunohistochemical analysis of the spleen of $A l o x 5^{+/+}$and $A l o x 5^{\prime-}$ mice after immunization with SRBCs (day 7). $\mathrm{CD}^{+} \mathrm{T}$ cells (green), CD19 ${ }^{+} \mathrm{B}$ cells (blue), and PNA ${ }^{+}$germinal center cells (red) are visualized. Original magnification: $\times 200$ (upper panel) and $\times 400$ (lower panel). D: FACS analysis of spleen cells of Alox $5^{+/+}$and Alox $5^{1-}$ mice before $($ day 0$)$ and after $($ day 7 ) immunization with SRBCs. After immunization, the population of germinal center cells $\left(\mathrm{B} 220^{+} \operatorname{IgD}^{-} \mathrm{PNA}^{+}\right)$of $A$ lox $5^{+/+}$mice increased from $0.5 \%$ to $8.3 \%$ of the total $\mathrm{B} 220^{+}$cells, whereas that of Alox $5^{-1}$ mice increased from $0.1 \%$ to only $1.0 \%$. E, F: A FACS analysis of follicular B cells (B220 $\left.{ }^{+} \mathrm{CD} 21^{\text {int }} \mathrm{CD} 23^{+}\right)$of the spleen. E: Follicular B cells compose $30 \%$ and only $18 \%$ of the total B $220^{+}$cell population in Alox $5^{+/+}$and Alox $5^{/-}$mice, respectively. F: Follicular B cells compose $26 \%$ and $15 \%$ of the total $\mathrm{B} 220^{+}$cell population in Rag $1^{W T}$ and Rag $1^{A l o x} 5$ mice, respectively. G: The expression levels of annexin $\mathrm{V}$ on follicular B cells of the spleen in Alox $5^{+/+}$, Alox $5^{+/-}$, and Alox $5^{-1}$ mice after administration of SRBCs (day 7) as assessed by means of FACS analyzer. The mean fluorescence intensity (MFI) of annexin V on follicular B cells is shown. H: Expression levels of the transcripts of cytokines and receptors of follicular B cells sorted from the spleen of Alox $5^{+/+}$and Alox $5^{-1-}$ mice as assessed by means of PCR. The left panel shows the RT-PCR results (25 cycles) investigating various molecules, including Alox 5 , and determines the down-regulation of the IL-21 receptor transcripts in the Alox ${ }^{-1}$ cells. The right panel presents results from quantitative PCR of the IL-21 receptor of follicular B cells, indicating that the IL-21 receptor levels in these cells of Alox $5^{-1}$ cells are approximately $20 \%$ of those in Alox $5^{+/+}$cells. Total, total spleen cells; NC, no template control. I: The expression levels of major histocompatibility complex class II on spleen cells of $A l o x 5^{+/+}$, Alox $5^{+/-}$, and Alox $5^{-}$ mice. FOB, follicular B cells; MZB, marginal zone B cells $\left(\mathrm{B} 220^{+} \mathrm{CD} 21^{\text {hi }} \mathrm{CD} 23^{-}\right)$; NFB, nonfollicular B cells (B220 ${ }^{+} \mathrm{CD} 21^{\mathrm{lo}} \mathrm{CD} 23^{-}$). The results presented are representative of three to four independent experiments. In each experiment, 3 to 10 mice per group were used. ${ }^{*} P<0.05$ compared with the wild-type control.

whether humoral immunity regulated by Alox5 would work as a defense mechanism against microorganisms, an experimental colitis model was used in which DSS was orally administered to the mice in a conventional facility. ${ }^{24}$ The results indicated that loss of Alox5 led to exaggerated enterocolitis (Figure 6A). Histologic examinations revealed severe erosion and an inflammatory reaction of the mucosa in Alox $5^{-1-}$ mice (Figure $6, \mathrm{~B}$ and $\mathrm{C}$ ). Similar results were observed in Rag $1^{\text {Alox5 }}$ mice, implying that the Alox5 of $B$ cells plays a pivotal role in establishing humoral immunity against pathogens under conventional conditions.

\section{Alox5 Enhances the Growth of MCLs}

Finally, we investigated the expression profiles of Alox5 in B-cell lymphomas composed of small lymphoid cells, including MCL, small lymphocytic lymphoma (SLL), and marginal zone lymphoma. Currently, naive B cells of the mantle zone, antigen-experienced $\mathrm{B}$ cells, and postgerminal center $\mathrm{B}$ cells are considered to be the postulated cell origins of MCL, SLL, and marginal zone lymphoma, respectively. ${ }^{43}$ Immunohistochemical studies using L22 $\mathrm{mAbs}$ on frozen sections revealed the high expression of Alox5 in MCL and SLL but not in marginal zone lymphoma (Figure 7, A-I). These results seem to be in agreement with our observations that Alox5 was preferentially presented in naive and memory B cells. When the $\mathrm{MCL}$ cell lines were examined, three cell lines, including G519, MINO, and REC1, possessed Alox5 (Figure 7J). Interestingly, AA861, an Alox5 inhibitor, possessed the capacity to reduce the growth of MINO cells (Figure 7K). Moreover, AA861 combined with vincristine, an antitumor re- 
A

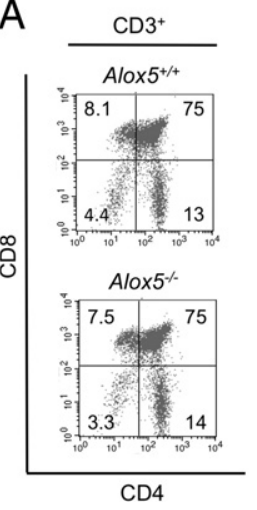

B

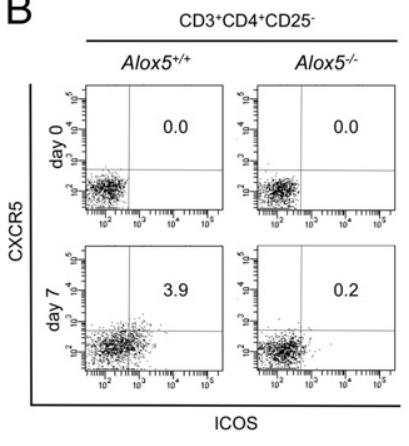

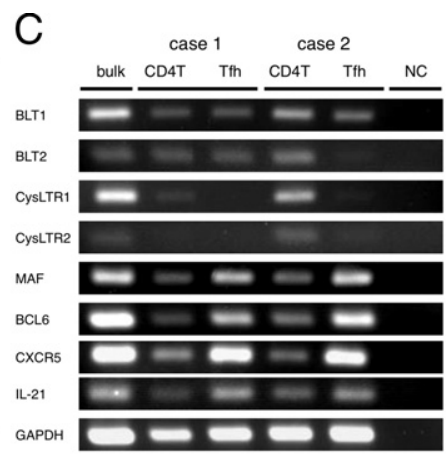

Figure 5. Developmental defects of Th cells in Alox5-deficient mice. A: FACS analysis of thymocytes in Alox $5^{+/+}$and Alox $5^{-1-}$ mice. The population recognized by the expression of $\mathrm{CD} 4$ and $\mathrm{CD} 8$ are shown. B: FACS analysis of spleen cells of Alox $5^{+/+}$ and Alox $5^{/-}$mice before (day 0) and after (day 7) immunization with SRBCs. After immunization, the population of Th cells $\left(\mathrm{CD}^{+} \mathrm{CD}^{+} \mathrm{CD} 25^{-}\right.$ $\mathrm{ICOS}^{+} \mathrm{CXCR}^{+}$) in Alox $5^{+/+}$mice increased from $0.0 \%$ to $3.9 \%$ of the total $\mathrm{CD} 3^{+} \mathrm{CD} 4^{+}$cells, and that of Alox $5^{-}$mice increased from $0.0 \%$ to $0.2 \%$. C: Expression levels of transcripts of leukotriene receptors in Tfh cells sorted from human tonsils. Results of two cases assessed by means of RT-PCR ( 28 cycles) are shown. Glyceraldehyde-3-phosphate dehydrogenase was used as the positive control. Bulk, total lymphocytes; NC, no template control. The results presented in (A) and (B) are representative of three to four independent experiments. In each experiment, three to six mice per group were tested.

agent for $\mathrm{MCL}$, resulted in dramatic reduction of the growth activities of MINO cells. Therefore, Alox5 may be associated with the cellular integrities of not only primary $\mathrm{B}$ cells of the mantle zone, from which they originate, but also of MCL cells.

\section{Discussion}

In this study, we followed comprehensive immunoprecipitation and proteomics methods to identify an L22 Ag as Alox5. As implicated by the expression of Alox5 in mantle zone $\mathrm{B}$ cells $\left(\mathrm{CD}_{2} 3^{+}\right.$and $\left.\mathrm{CD}_{2} 3^{-}\right)$around germinal centers, Alox5 plays a pivotal role in specific immunity as a regulator of cell fate and responsiveness to IL-21 of naive follicular B cells. ${ }^{37,38,44}$ Alox5 defects also impinge on the

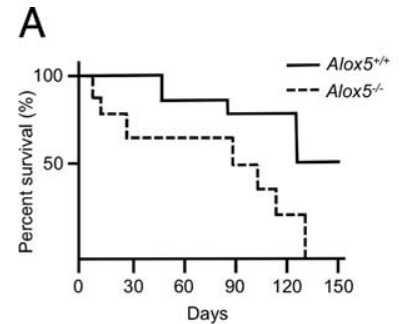

B
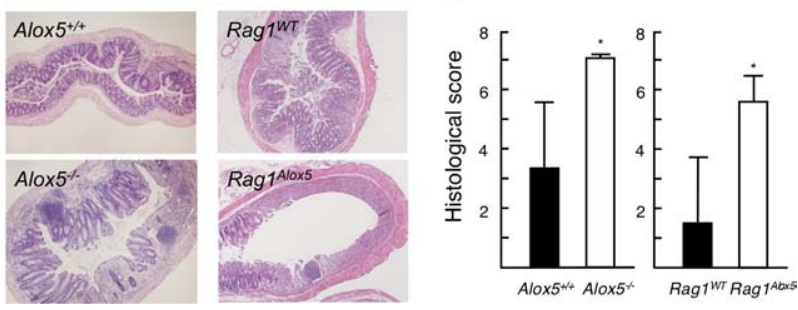

Figure 6. Alox 5 defects attenuate intestinal tissue damage, with high mortality in experimentally induced chronic enterocolitis models. A: Survival curves of DSS-induced colitis models. Mice were maintained in a conventional facility and were allowed to freely drink water containing $1.5 \%$ DSS The left and right panels illustrate the percentage survivals of Alox $5^{+/+}$and Alox $5^{-1}$ mice and $\operatorname{Rag} 1^{W T}$ and $\operatorname{Rag} 1^{A l o x 5}$ mice, respectively. $n=7$ to 8 per group. B: Histologic findings of mice intestines after DSS administration on day 7 . The left and right panels demonstrate the intestines of Alox $5^{+/+}$or Alox $5^{-1-}$ mice and Rag $1^{W T}$ or Rag $1^{\text {Alox } 5}$ mice, respectively. The intestines of Alox $5^{-1-}$ and Rag $1^{\text {Alox } 5}$ mice manifested severe enterocolitis. Original magnification, $\times 100$. C: The total histologic score is presented as mean with SEM ( $n=3$ to 4 mice per group). ${ }^{*} P<0.05$ compared with the wild-type control. generation of memory B cells, suggesting that it would completely support the preservation of B-cell repertories maintained by naive and memory $B$ cells. The Alox 5 pathway is essentially associated with a variety of inflammatory diseases, including asthma, atherosclerosis, rheumatoid arthritis, liver cirrhosis, and cancer, which are caused by an underlying anomaly of acquired immunity. ${ }^{15,31}$ Therefore, primary B cells may act as a modulator in these pathologic situations. As a major source of leukotrienes in lymphoid tissues, primary B cells may contribute to establishment of the histologic features, such as lymphadenitis lesions.

Infection of mice with RNA or DNA viruses induces an antiviral antibody response, which is largely restricted to IgG2a. This also provides the functional importance of Alox5 as a coordinator of host defense. The regulation of IgG2a, which is an IL-4-independent Ig isotype, and the mechanism of interferon $\gamma$ derived from type I helper $T$ cells remain investigative priorities. Although we could not fully elucidate the precise mechanism of IgG2a production by Alox5, it has been previously reported that Alox5 deficiency may lead to an imbalance of type I and II helper T cells. ${ }^{45}$ Thus far, we considered the possible involvement of Alox5 in the development of helper T-cell subpopulations. CD4 ${ }^{+} \mathrm{T}$ cells possess leukotriene receptors, which can instructively work for the mobilization of effector $\mathrm{T}$ cells to inflammatory foci; however, little is known about the role of leukotrienes in the development of Tfh cells. ${ }^{14,40-42,46}$ Leukotriene receptors encoded in germlines form a receptor spanning seven membranes coupled with G-proteins in the cytoplasm, similar to the chemokine receptors of Tfh cells, such as CXCR5, CCR6, and CXCR3. Leukotriene receptors seem to be downregulated (or at least not up-regulated) in Tfh cells; therefore, such lipid mediators might act on the initial process of differentiation of naive helper $T$ cells. The prerequisite for the differentiation of naive helper $T$ cells is the interaction of the T-cell receptor on naive $\mathrm{CD}^{+}{ }^{+}$helper cells with major histocompatibility complex class II molecules on professional APCs. Therefore, professional APCs, which express Alox5, profoundly affect the initial steps of the differentiation of naive helper $T$ cells. Rag $1^{\text {Alox } 5}$ mice exhibited defects of specific antibody responses to foreign antigens, although Tfh cells could be recognized in response to the administration of foreign antigens in these 

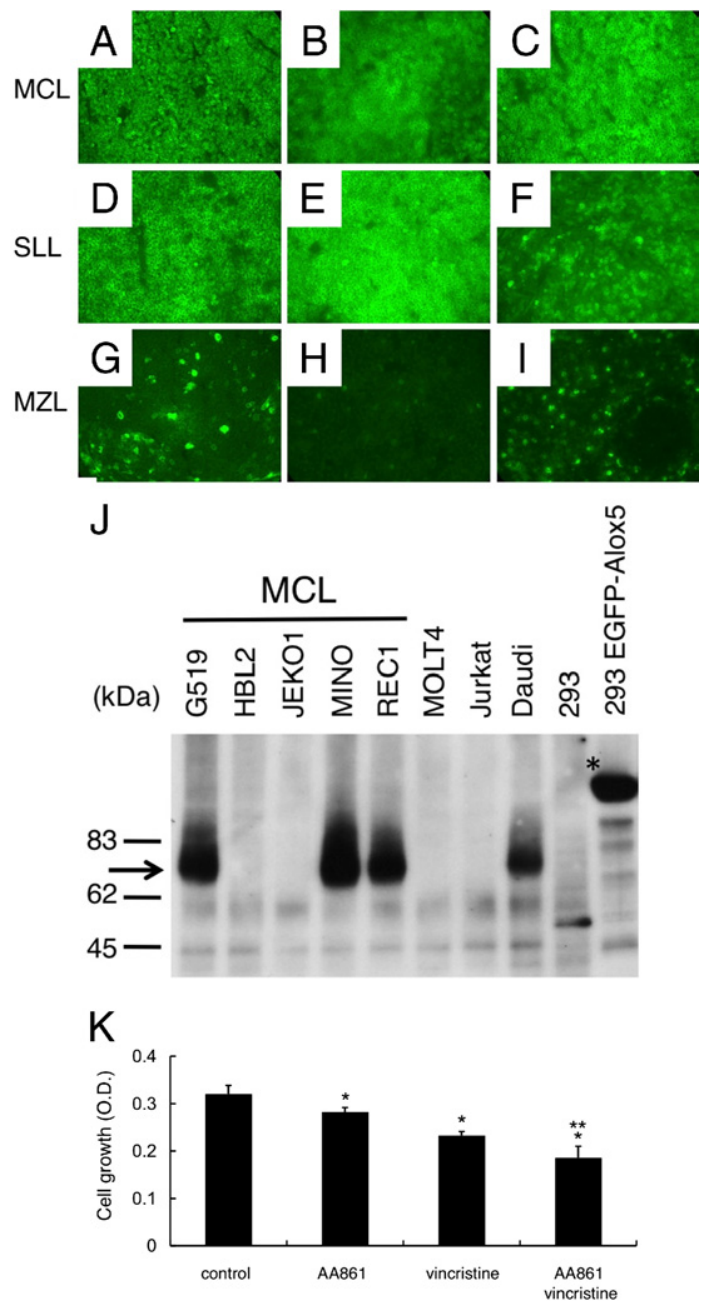

Figure 7. Alox 5 defines cell growth of mantle cell-derived B-cell malignancies. A-I: Alox 5 expression in B-cell lymphomas composed of small lymphoid cells. Immunohistochemical analysis using L22 mAbs was performed on frozen sections of independent tumor tissues: MCL (A-C), SLL (D-F), and marginal zone lymphoma (MZL) $(\mathbf{G}-\mathbf{I})$. Original magnification, $\times 200$. J: Alox 5 expression in cells derived from MCL at the protein level (arrow). Immunoblot analysis with anti-Alox 5 pAbs was performed on human cell lines. HEK 293 cells with or without EGFP-Alox 5 (asterisk) were used as the control. K: Cell growth of MINO under $10 \mu \mathrm{mol} / \mathrm{L}$ AA861 or $50 \mu \mathrm{g} / \mathrm{ml}$ of vincristine assessed by using WST1. A 96-well plate containing $1 \times 10^{5}$ cells per well was incubated with reagents for 24 hours. Results are representative of four independent experiments. ${ }^{*} P<0.01$ compared with the control; ${ }^{* * *} P$ $<0.05$ compared with vincristine alone.

mice (data not shown). Thus, the lipid mediators derived from macrophages or dendritic cells but not from B cells would affect the process of differentiation of Tfh cells.

In this study, we could not fully elucidate a mechanism of the production of leukotrienes from primary B cells. Macrophages or dendritic cells produce Alox5-related leukotrienes by activating cytosolic phospholipase A2. It may be supposed that B-cell receptor signaling leads to the mobilization of calcium ions through inositol phosphate, leading to the activation of cytosolic phospholipase A2 and the subsequent liberation of arachidonate from membrane glycerolipids as a substrate of Alox5. We observed that Alox $5^{-1-}$ mice can produce B1 B cells $\left(\mathrm{B}^{2} 2 \mathrm{O}^{+} \mathrm{CD}^{+} \mathrm{IgM}^{+}\right)$, related to producing natural antibodies, in the spleen and peritoneal cavity (data not shown). In this context, leukotrienes of primary B2 B cells may regulate the adaptive humoral immune response. ${ }^{47}$ Indeed, we found transcripts of Alox5 in mouse follicular $B$ cells, and we are trying to detect Alox5 in these cells at protein levels.

Maintenance of the $\mathrm{B}$-cell repertoire is one of the most important elements in achieving adaptive humoral responses and protecting the host from pathogens. Perhaps primary naive and memory B cells express Alox5 and preserve their integrity to maintain the B-cell repertoire. According to this story, it was of interest to note that $\mathrm{MCL}$, one of the most refractory tumors against conventional therapies, might depend at least in part on the function of Alox5 in terms of cellular growth. The evidence that primary $B$ cells and $\mathrm{MCL}$, which originates from primary $\mathrm{B}$ cells, rely on Alox5 for their cellular integrity can provide insights for understanding the unique tumor biology of MCLs. Further investigations should elucidate the mechanism of the additive effects of Alox5 inhibitors as chemotherapeutic reagents to treat MCL. ${ }^{48,49}$

In summary, we demonstrated the fundamental role of Alox5 in establishing specific antibody responses. Alox5 regulates not only primary resting $B$ cells of the naive and memory B-cell phenotypes but also Tfh cell generation, thereby preserving specific antibody production. It has not yet been determined whether Alox5-related lipid mediators take part in the plasticity of the generation of helper T cells. However, studies of the expression profiles of leukotriene receptors on helper T-cell species would enable us to recognize the biological significance of lipid mediators in the differentiation of helper $\mathrm{T}$ cells. Lipid metabolism of arachidonic acid, affected by amounts from the oral intake or function of related enzymes, may affect the primary B-cell response by altering IL-21- and Tfh-mediated stimulation.

\section{Acknowledgments}

We thank Dr. Jose A. Martinez-Climent (University of Navarra, Pamplona, Spain) for providing MCL cell lines.

\section{References}

1. Watt V, Ronchese F, Ritchie D: Resting B cells suppress tumor immunity via an MHC class-II dependent mechanism. J Immunother 2007, 30:323-332

2. Vinuesa CG, Sanz I, Cook MC: Dysregulation of germinal centres in autoimmune disease. Nat Rev Immunol 2009, 9:845-857

3. Rodríguez-Pinto D: B cells as antigen presenting cells. Cell Immunol 2005, 238:67-75

4. Kurosaki $\mathrm{T}$, Shinohara $\mathrm{H}$, Baba Y: B cell signaling and fate decision. Annu Rev Immunol 2010, 28:21-55

5. McHeyzer-Williams LJ, McHeyzer-Williams MG: Antigen-specific memory B cell development. Annu Rev Immunol 2005, 23:487-513

6. Schmidlin H, Diehl SA, Blom B: New insights into the regulation of human B-cell differentiation. Trends Immunol 2009, 30:277-285

7. Ishii Y, Takami T, Yuasa H, Takei T, Kikuchi K: Two distinct antigen systems in human B lymphocytes: identification of cell surface and intracellular antigens using monoclonal antibodies. Clin Exp Immuno 1984, 58:183-192 
8. Takami T, Ishii Y, Yuasa H, Kikuchi K: Three distinct antigen systems on human $B$ cell subpopulations as defined by monoclonal antibodies. J Immunol 1985, 134:828-834

9. Kokai $Y$, Ishii $Y$, Kikuchi K: Characterization of two distinct antigens expressed on either resting or activated human $B$ cells as defined by monoclonal antibodies. Clin Exp Immunol 1986, 64:382-391

10. Murakami YI, Yatabe Y, Sakaguchi T, Sasaki E, Yamashita Y, Morito N, Yoh K, Fujioka $Y$, Matsuno $F$, Hata $H$, Mitsuya $H$, Imagawa $S$ Suzuki A, Esumi H, Sakai M, Takahashi S, Mori N: c-Maf expression in angioimmunoblastic T-cell lymphoma. Am J Surg Pathol 2007, 31: 1695-1702

11. Rådmark $O$, Werz $O$, Steinhilber D, Samuelsson B: 5-Lipoxygenase: regulation of expression and enzyme activity. Trends Biochem Sci 2007, 32:332-341

12. Mahshid $Y$, Lisy MR, Wang X, Spanbroek R, Flyqare J, Christensson B, Björkholm M, Sander B, Habenicht AJ, Claesson HE: High expression of 5-lipoxygenase in normal and malignant mantle zone $\mathrm{B}$ lymphocytes. BMC Immunol 2009, 10:1-12

13. Toyama H, Okada S, Hatano M, Takahashi $Y$, Takeda N, Ichii H, Takemori T, Kuroda Y, Tokuhisa T: Memory B cells without somatic hypermutation are generated from Bcl6-deficient B cells. Immunity 2002, 17:329-339

14. King C, Tangye SG, Mackay CR: T follicular helper (TFH) cells in normal and dysregulated immune responses. Annu Rev Immunol 2008, 26:741-766

15. Fazilleau N, Mark L, McHeyzer-Williams LJ, McHeyzer-Williams MG: Follicular helper T cells: lineage and location. Immunity 2009, 30: 324-335

16. Amirav I, Luder AS, Kruger N, Borovitch Y, Babai I, Miron D, Zuker M, Tal G, Mandelberg A: A double-blind, placebo-controlled, randomized trial of montelukast for acute bronchiolitis. Pediatrics 2008, 122 : 1249-1255

17. Medeiros AI, Sá-Nunes A, Turato WM, Secatto A, Frantz FG, Sorgi CA, Serezani CH, Deepe DS Jr., Faccioli LH: Leukotrienes are potent adjuvant during fungal infection: effects on memory T cells. J Immunol 2008, 181:8544-8551

18. Boyd RS, Jukes-Jones R, Walewska R, Brown D, Dyer MJ, Cain K: Protein profiling of plasma membranes defines aberrant signaling pathways in mantle cell lymphoma. Mol Cell Proteomics 2009, 8:1501-1515

19. Chen XS, Sheller JR, Johnson EN, Funk CD: Role of leukotrienes revealed by targeted disruption of the 5-lipoxygenase gene. Nature 1994, 372:179-182

20. Koshiba S, Ichimiya S, Nagashima T, Tonooka A, Kubo T, Kikuchi T, Himi T, Sato N: Tonsillar crypt epithelium of palmoplantar pustulosis secretes interleukin-6 to support B-cell development via p63/p73 transcription factors. J Pathol 2008, 214:75-84

21. Tonooka A, Kubo T, Ichimiya S, Tamura Y, IImarinen T, Ulmanen I, Kimura S, Yokoyama S, Takano Y, Kikuchi T, Sato N: Wild-type AIRE cooperates with p63 in HLA class II expression of medullary thymic stromal cells. Biochem Biophys Res Commun 2009, 379:765-770

22. Hanaka H, Shimizu T, Izumi T: Stress-induced nuclear export of 5-lipoxygenase. Biochem Biophys Res Commun 2005, 338:111-116

23. Muramatsu M, Kinoshita K, Fagarasan S, Yamada S, Shinkai Y, Honjo $\mathrm{T}$ : Class switch recombination and hypermutation require activationinduced cytidine deaminase (AID), a potential RNA editing enzyme. Cell 2000, 102:553-563

24. Obermeier F, Dunger N, Deml L, Herfarth H, Schomerich J, Falk W: CpG motifs of bacterial DNA exacerbate colitis of dextran sulfate sodium-treated mice. Eur J Immunol 2002, 32:2084-2092

25. Shen Y, Iqbal J, Huang JZ, Zhou G, Chan WC: BCL2 protein expression parallels its mRNA level in normal and malignant $B$ cells. Blood 2004, 104:2936-2939

26. Radwanska M, Guirnalda P, De Trez C, Ryffel B, Black S, Magez S: Trypanosomiasis-induced $\mathrm{B}$ cell apoptosis results in loss of protective anti-parasite antibody responses and abolishment of vaccineinduced memory responses. PLoS Pathog 2008, 4:e1000078

27. Sanz I, Wei C, Lee FE, Anolik J: Phenotypic and functional heterogeneity of human memory B cells. Semin Immunol 2008, 20:67-82

28. Sukumar S, Conrad DH, Szakal AK, Tew JG: Differential T cellmediated regulation of CD23 (Fc epsilonRII) in B cells and follicular dendritic cells. J Immunol 2006, 176:4811-4817
29. Huggins J, Pellegrin T, Felgar RE, Wei C, Brown M, Zheng B, Milne EC, Bernstein SH, Sanz I, Zand MS: CpG DNA activation and plasmacell differentiation of CD27-naive human B cells. Blood 2007, 109 1611-1619

30. Richards S, Watanabe C, Santos L, Craxton A, Clark EA: Regulation of B-cell entry into the cell cycle. Immunol Rev 2008, 224:183-200

31. Shimizu T: Lipid mediators in health and disease: enzymes and receptors as therapeutic targets for the regulation of immunity and inflammation. Annu Rev Pharmacol Toxicol 2009, 49:123-150

32. Finkelman FD, Katona IM, Mosmann TR, Coffman RL: IFN-gamma regulates the isotypes of Ig secreted during in vivo humoral immune responses. J Immunol 1988, 140:1022-1027

33. Qazi KR, Gehrmann U, Domange Jordö E, Karlsson MC, Gabrielsson S: Antigen-loaded exosomes alone induce Th1-type memory through a B-cell-dependent mechanism. Blood 2009, 113:2673-2683

34. Pillai S, Cariappa A: The follicular versus marginal zone B lymphocyte cell fate decision. Nat Rev Immunol 2009, 9:767-777

35. Bialecki E, Paget C, Fontaine J, Capron M, Trottein F, Faveeuw C: Role of marginal zone B lymphocytes in invariant NKT cell activation. J Immunol 2009, 182:6105-6113

36. Casciola-Rosen L, Rosen A, Petri M, Schlissel M: Surface blebs on apoptotic cells are sites of enhanced procoagulant activity: implications for coagulation events and antigenic spread in systemic lupus erythematosus. Proc Natl Acad Sci U S A 1996, 93:1624-1629

37. Ozaki K, Spolski R, Feng CG, Qi CF, Cheng J, Sher A, Morse HC III, Liu C, Schwartzberg PL, Leonard WJ: A critical role for IL-21 in regulating immunoglobulin production. Science 2002, 298:16301634

38. De Totero D, Meazza R, Zupo S, Cutrona G, Matis S, Colombo M Balleari E, Pierri I, Fabbi M, Capaia M, Azzarone B, Gobbi M, Ferrarin M, Ferrini S: Interleukin-21 receptor (IL-21R) is up-regulated by CD40 triggering and mediates proapoptotic signals in chronic lymphocytic leukemia B cells. Blood 2006, 107:3708-3715

39. Spanbroek R, Hildner M, Steinhilber D, Fusenig N, Yoneda K, Rådmark O, Samuelsson B, Habenicht AJ: 5-lipoxygenase expression in dendritic cells generated from CD34(+) hematopoietic progenitors and in lymphoid organs. Blood 2000, 96:3857-3865

40. Vogelzang A, McGuire HM, Yu D, Sprent J, Mackay CR, King C: A fundamental role for interleukin-21 in the generation of $\mathrm{T}$ follicular helper cells. Immunity 2008, 29:127-137

41. Bauquet AT, Jin H, Paterson AM, Mitsdoerffer M, Ho IC, Sharpe AH, Kuchroo VK: The costimulatory molecule ICOS regulates the expression of c-Maf and IL-21 in the development of follicular T helper cells and TH-17 cells. Nat Immunol 2009, 10:167-175

42. Nurieva RI, Chung Y, Martinez GJ, Yang XO, Tanaka S, Matskevitch TD, Wang YH, Dong C: Bcl6 mediates the development of T follicula helper cells. Science 2009, 325:1001-1005

43. Swerdlow SH, Campo E, Harris NL, Jaffe ES, Pileri SA Stein H, Thiele J, Vardiman JW: WHO Classification of Tumours of Haematopoietic and Lymphoid Tissues, ed 4. IARC Press, Lyon, France, 2008

44. Ettinger R, Kuchen S, Lipsky PE: The role of IL-21 in regulating B-cel function in health and disease. Immunol Rev 2008, 223:60-86

45. DiMeo D, Tian J, Zhang J, Narushima S, Berg DJ: Increased interleukin-10 production and Th2 skewing in the absence of 5-lipoxygenase. Immunology 2008, 123:250-262

46. Tager AM, Bromley SK, Medoff BD, Islam SA, Bercury SD, Friedrich EB, Carafone AD, Gerszten RE, Luster AD: Leukotriene B4 receptor BLT1 mediates early effector T cell recruitment. Nat Immunol 2003 4:982-990

47. Bafica A, Scanga CA, Serhan C, Machado F, White S, Sher A, Alibert $\mathrm{J}$ : Host control of Mycobacterium tuberculosis is regulated by 5-lipoxygenase-dependent lipoxin production. J Clin Invest 2005, 115 1601-1606

48. Runarsson G, Liu A, Mahshid Y, Feltenmark S, Pettersson A, Klein E Björkholm M, Claesson HE: Leukotriene B4 plays a pivotal role in CD40-dependent activation of chronic B lymphocytic leukemia cells. Blood 2005, 105:1274-1279

49. Ihara A, Wada K, Yoneda M, Fujisawa N, Takahashi $H$, Nakajima A Blockade of leukotriene B4 signaling pathway induces apoptosis and suppresses cell proliferation in colon cancer. J Pharmacol Sci 2007 103:24-32 